\title{
Does Sensitization to Food Allergens in Patients with Rhinitis Mean Food Allergy?
}

Nelson Rosario* and Laura Maria Lacerda Araujo

Pediatric Allergist, Postgraduate Student, Department of Pediatrics, Federal University of Parana, Brazil

Molecular based diagnostics (MD) is used to map the allergen sensitization of a patient at a molecular level, using allergen components instead of total allergenic extracts. It is increasingly entering routine care and currently, there are more than 130 allergen components available for in vitro specific IgE testing $[1,2]$. One of the main roles of $\mathrm{MD}$ is in food allergy diagnosis and prevention: resolving genuine versus cross-reactive sensitization to an allergen component, thereby improving the understanding of triggering allergens and assessing the risk of severe reactions based on defining allergen stability [1-3].

To verify the frequency of positive specific IgE to food allergens in patients with respiratory allergic diseases using molecular analysis, a cross-sectional study involved 101 children and adolescents (aged 6-18 years) diagnosed with allergic rhinitis in Curitiba, Southern Brazil. None of subjects presented food allergy history. The study was approved by the Institution Review Board of Research Projects and written informed consent was obtained from the parents or caregivers. Patients underwent serum specific IgE analysis by Immuno CAP ISAC, a method that employs molecular biology for detection of allergic components, 42 of them related to food and coming from the following sources: pineapple, celery, peanut, hazelnut, codfish, shrimp, carp, cashew nut, Brazil nut, carrot, sesame, kiwi, cow's milk, apple, egg, peach, soy and wheat. The test was considered positive if values were $\geq$ 0,3ISU (ISAC standardized units) [4]

\section{Descriptive Statistics Analysis}

Although none of the participants had food allergy symptoms, twenty seven $(26.7 \%)$ presented specific IgE to at least one of the food allergens tested. Among the 42 allergic components from food sources tested, $20(47.6 \%)$ were positive in at least one of the patients. Allergens that had the higher frequency of reactivity were: shrimp (Pen a $115.8 \%$, Pen i 1 16.8\%, Pen $\mathrm{m} 1$ 16.8\%) and peach (Pru p 3 5.9\%). Pen a 1, Pen i 1 and Pen $\mathrm{m} 1$ can present cross-reactivity with Der p 10, allergen component from the mite species Dermatophagoides pteronyssinus, detected among $15.8 \%$ participants (data not shown). Probably, specific IgE positivity to these allergens occurred due to the presence of tropomyosin, a protein identified in both food (crustaceans, mollusks) and inhalant components (house dust mites, cockroaches). Therefore, the presence of IgE to shrimp allergen components in this case means sensitization, and not true food allergy [5,6]. Peach component Pru $p$ 3 , whose protein is known as LTP (lipid transfer protein) was detected in a relatively high rate. LTPs are considered panallergens that crossreact with pollen components. All participants with positive specific IgE to Pru p 3 were also positive to Pla a 2, a platanus component (data not shown). Again, this was probably due to cross-reactivity, meaning sensitization, not food allergy. Lipid transfer protein (LTP) can cause clinically relevant food allergy symptoms even at low sIgE concentrations. Positivity to the panallergen Pru p 3 is a predictor of severe food allergy in these patients. A follow-up of our patients for clinical symptoms of food allergy may demonstrate the importance of this LTP asymptomatic patients $[7,8]$.

Cross-reactive Carbohydrate Determinants (CCDs) are widely distributed in plants and approximately $20 \%$ of patients with pollen allergy have IgE antibodies which bind on carbohydrate determinants. Our patients did not have seasonal symptoms but it could be interesting to verify how many of them were sensitized to CCD epitopes [2].

The evaluation of food allergy based on molecular analysis must consider several factors, particularly the correlation with clinical symptoms and knowledge of IgE cross-reactivity between allergens from different sources. Incorrect diagnosis of food allergy can lead to inappropriate treatment, with unnecessary restrictive diets and nutritional consequences for the patients.

\section{References}

1. Mari A (2008) When does a protein become an allergen? Searching for a dynamic definition based on most advanced technology tools. Clin Exp Allergy 38: 1089-1094.

2. Canonica GW, Ansotegui IJ, Pawankar $R$, Schmid-Grendelmeier $P$, van Hage $\mathrm{M}$, et al. (2013) A WAO - ARIA - GA2 LEN consensus document on molecularbased allergy diagnostics. World Allergy Organ J 6: 17

3. Harwanegg C, Hiller R (2005) Protein microarrays for the diagnosis of allergic diseases: state-of-the-art and future development. Clin Chem Lab Med 43 $1321-1326$.

4. Scala E, Alessandri C, Bernardi ML, Ferrara R, Palazzo P, et al. (2010) Cross sectional survey on immunoglobulin $E$ reactivity in 23077 subjects using an allergenic molecule- based microarray detection system. Clin Exp Allergy 40: 911-921.

5. Aalberse RC (1998) Allergens from mites: implications of cross-reactivity between invertebrate antigens. Allergy 53: 47-48.

6. Alessandri C, Zennaro D, Zaffiro A, Mari A (2009) Molecular allergology approach to allergic diseases in the paediatric age. Ital J Pediatr 35: 29.

7. Pascal M, Muñoz-Cano R, Reina Z, Palacín A, Vilella R, et al. (2012) Lipid transfer protein syndrome: clinical pattern, cofactor effect and profile of molecular sensitization to plant-foods and pollens. Clin Exp Allergy 42: 15291539.

8. Letrán A, Espinazo M, Moreno $F$ (2013) Measurement of IgE to pollen allergen components is helpful in selecting patients for immunotherapy. Ann Allergy Asthma Immunol 111: 295-297.

*Corresponding author: Nelson Rosario, Department of Pediatrics, Federa University of Parana, Brazil, Tel: 5541 91015181; Fax: 55413208 6500; E-mail: nelson.rosario@ufpr.br

Received February 25, 2014; Accepted March 27, 2014; Published March 31, 2014

Citation: Rosario N, Araujo LML (2014) Does Sensitization to Food Allergens in Patients with Rhinitis Mean Food Allergy? J Allergy Ther 5: 167. doi:10.4172/2155 6121.1000167

Copyright: ( 2014 Rosario N, et al. This is an open-access article distributed unde the terms of the Creative Commons Attribution License, which permits unrestricted use, distribution, and reproduction in any medium, provided the original author and source are credited. 